\title{
The Importance of Improving the Quality of Civil Servants to Implement E- Government Service Delivery in Industrial Era 4.0: A Case Study Approach of Government Institutions in Jakarta
}

\author{
Siti Nurbaity, S.AB, MA* \\ Bekasi, Indonesia \\ *Corresponding Author \\ Siti Nurbaity \\ Article History \\ Received: 16.10.2019 \\ Accepted: 24.10 .2019 \\ Published: 11.11.2019
}

Business and Administration Program, STIAMI- Institute of Social Sciences and Management, Jl. Kartini No 10, Margahayu, Kota

\begin{abstract}
This study aims at answering the questions on how the readiness of civil servant is in facing of the Industrial Revolution 4.0 and what the government's efforts to improve the quality of civil servants in order to run E- Service delivery in the Industrial Era 4.0.This study employed a case study approach of a qualitative research design. The participants for in depth interview consists of 15 people namely civil servants from 3 government institutions in Jakarta to gain information about the implementation of E- Service delivery and the barriers that they faced, Human Resources Managers to dig deeper their perspectives on the readiness of the institutions and civil servants to face the IR 4.0. Finally, the interviews were also conducted to IT specialists of 3 institutions to gain information on their perspectives towards the digital competencies of the civil servants. The research proves that the government institutions in Jakarta still found barriers in implementing the E-Service delivery, even though Indonesia has established a regulation since 2003. The obstacles were caused by the limited knowledge and skills on technology of the staff which was not followed by effective training management and supervision. For further study, the researcher recommends to conduct E-Service delivery policy research which is analyzed from different approach.
\end{abstract}

Keywords: Civil servant, E-Government service delivery, industrial era 4.0.

\section{INTRODUCTION}

Today we are entering the era of the industrial revolution 4.0, meaning the 4th stage of the revolution. If the first industrial revolution was marked by the invention of the printing press and steam engine, the second industrial revolution, marked the invention of electricity, then the 3rd industrial revolution marked the presence of telephones and mobile phones, internet, IT, biological development and genetic engineering, the 4th industrial revolution is the era of the application of modern technology, including fiber technology and integrated network systems, or the impact of networks in all fields of life, the inclusion of artificial intelligence (artificial intelligence), increasingly sophisticated computing technology and also the phenomenon of the Internet of Things (IOT) have been so massive in the middle of society. An example is the mobile phone we use every day that has used a face scanner system. That is one example of artificial intelligence. In a millennium era like today where the role of technology is so sophisticated, the role of humans will gradually be replaced by the sophistication of the technology. Internet penetration that will reach all regions in Indonesia has the potential to undermine the role of civil servants in various ministries / local governments.

The organizational structure of the government which has been mechanistic, bureaucratic hierarchical, rigid departmentalization, high formalization and centralized needs to be continuously transformed. Lack of access to the internet or other communication channels can make information from the government center late received to all employees who are spread throughout the country. Technological advancements that can accelerate bureaucratic work and make it easier for people to get services are not easily implemented.

The organizational level innovation must always be developed to respond to the challenges and demands of increasingly complex community needs. The structure of government organizations up to now have been rigidly possible to be aligned with

Copyright @ 2019: This is an open-access article distributed under the terms of the Creative Commons Attribution license which permits unrestricted use, distribution, and reproduction in any medium for non commercial use (NonCommercial, or CC-BY-NC) provided the original author and source are credited. 
technological developments. The Industrial Revolution 4.0 provides great opportunities in streamlining the functions and roles of government organizations in carrying out their daily tasks, rapid IT development can be an opportunity in accelerating the application of e-governance, as digitizing data and information such as e-budgeting, e-project planning, delivery systems, administration, econtrolling, e-reporting to e-monitoring and many other applications that can be developed to answer the needs of the community.

The quality of the state civil servants is currently far from what is expected [1]. In addition to their lack of expertise, their motivation in serving the community is still very low. Of the total civil servants in Indonesia which is amounting to 4.286. 918 million, $64 \%$ of them only have administrative capabilities [2]. Meanwhile data from the Ministry of State Apparatus 2019 there were 1,643,535 people $(37.70 \%)$ of the civil servants were general administration, 1,636,322 (37.60\%) teachers, structural positions of 434,488 (9.99\%), functional technical positions $372,740(8.57 \%)$, and health $264,305(6.07 \%)$. The status was divided into two, namely civil servants and government employees with work agreements.

The results of the assessment and competency (talent pool) of the National Personnel Agency (BKN) to thousands of civil servants showed less encouraging results. Meanwhile, most of the data in the Ministry of Transportation or almost 60 percent of its employees are still of Diploma, High School or lower educational background. At present, there are many civil servants have been placed not in accordance with the training received. So there are still no matches between the training program and the placement or position of these, so that what we expect from the training cannot be optimal when it comes to implementation, especially in the workplace of each agency both central and regional.

As a driving force for government, civil servants have an important role in improving the quality of planning and synergy between central and regional development plans to achieve the development of mission and vision. Therefore smart and quality civil servants is an important factor to achieve the development goals and to respond to challenges that will be faced in the future such as the 4th industrial revolution and also the E-Government. Therefore, this paper is intended to answer the questions on how the readiness of civil servant is in facing of the Industrial Revolution 4.0 and what the government's efforts are to improve the quality of civil servants in order to run E- Service delivery in the Industrial Era 4.0.

\section{LITERATURE REVIEW \\ Human Capital in an organization}

According to Schultz [3], the term "human capital" has been defined as a key element in improving a firm assets and employees in order to increase productive as well as sustain competitive advantage. Human capitals refer to processes that relate to training, education and other professional initiatives in order to increase the levels of knowledge, skills, abilities, values, and social assets of an employee which will lead to the employee's satisfaction and performance, and eventually on a firm performance [4]. Rastogi [5] states that human capital is an important input for organizations especially for employees' continuous improvement mainly on knowledge, skills, and abilities. Based on Organization for Economic Co-Operation and Development or OECD [6], human capital is referred to as "the knowledge, skills, competencies, and attributes embodied in individuals that facilitate the creation of personal, social and economic well-being". Becker [7] notes the most valuable of all capital is that investment in human being. Becker distinguishes firm-specific human capitals from general-purpose human capital.

Wright et al., [8] argue that intellectual capital is a factor that includes human capital, social capital and organizational capital. Social relationships and the social capital therein, are an important influence on the development of both human and intellectual capital. At the individual level, individuals with better social capital - individuals with stronger contact networks - will 'earn higher rates of return on their human capital' [9]. However, the principal role of organizational capital is to link the resources of the organization together into process that create value for customers and sustainable competitive advantage for the firm [10].

The connections between human capital, social capital and organizational capital will produce intellectual capital. This, in turn, will affect the management of knowledge within the organization. Knowledge has long been recognized as a valuable resource by economists and has been a focus of significant attention in the human capital literature, in particular the issues of knowledge generation, leverage, transfer and integration [8, 11-13]. Alnachef and Alhajjar [14] state that in an organizational context, human capital development is the process by which organizations help their employees in a continuous and planned way in order to: acquire or sharpen the abilities required to perform various functions associated with their present or expected future roles; develop their general skills as individuals, discover and utilize their inner potential for their own and/or organizational development purposes; develop an organizational culture in which supervisor subordinate relationships, teamwork and collaboration among sub-units are strong and contribute to the professional well-being, motivation, and pride of employees.

According to the research of Nahapiet \& Ghoshal, intellectual capital refers to the 'knowledge and knowing capability of a social collectively, such as an organization, intellectual community, or professional practice' [15]. In one study, Gratton \& Ghoshal [16] argue that intellectual capital is part of human capital, that is, human capital subsumes intellectual capital, and also includes within it social capital and emotional capital. While, Gartner [17] affirms that human capital is an arrangement of practices identified with individuals asset management, particularly in the classifications of workforce securing, management and advancement. 
Notwithstanding the customary authoritative undertakings, it incorporates workforce arranging and system, recruitment on boarding, employee training, revealing and investigation. Thusly, it is the reason for working in an organization for ideal performance.

\section{E Government Service Delivery in Industrial Revolution 4.0}

Osborne and Gaebler [18] defined E-Government as "The government's use of technology, in particular, web-based Internet applications to enhance access and delivery of government services to citizens, business partners, employees and other government entities." It is a way for governments to use the new technologies to provide people with more convenient access to government information and services, to improve the quality of the services and to provide greater opportunities to participate in our democratic institutions and processes.

The World Bank [19] define E-Government as the use by government agencies of information technologies (such as Wide Area Networks, the Internet, and mobile computing) that have the ability to transform relations with citizens, businesses, and other arms of government. These technologies can serve a variety of different ends: better delivery of government services to citizens, improved interactions with business and industry, citizen empowerment through access to information, or more efficient government management. The resulting benefits can be less corruption, increased transparency, greater convenience, revenue growth, and/or cost reductions. According to Karokola, Kowalski, \& Yngstrom [20], E-government refers to "government systems of ICT to transform relations with citizens, the private sector and other government agencies in order to enhance empowerment of citizens, government efficiency and delivery of service, increased transparency and accountability. E-government refers to the capability of various government agencies to provide government information and services at any time to citizens using electronic means speedily and properly, resulting in less costs and effort via a single Internet site" [21]. Zhang and Hou [22] defined E-Government as "the information technology use (particularly the Internet) by government to enhance operations of government, enhance citizens' participation, and provide services".

According to Fang [23], E-Government can be defined as a measure for the government to use the most innovative information and communication technology in the form of web-based internet applications, to provide ease of access to citizens and businesses, particularly relating to information and government services. In addition, Fang [23] went on to add that the existence of EGovernment can improve service quality and provide greater opportunities for the public to participate in the institutions and also to the democratic process. Ronaghan [24] states that the implementation of e-government aims to improve the efficiency, effectiveness and sustainable public services in line with national goals. In addition, e-government has the potential to build stronger institutional capacity for better service delivery to citizens and businesses. This can help reduce the potential for corruption prevailing in the country by increasing the transparency and social control. Warkentin et al., [25] state that among the characteristics of an effective EGovernment are the wide use of communication technology, online environment, data collection facilities and user-friendliness. Odat [21] developed a general framework concerning challenges and opportunities that confront e-government project implementation in developing countries, This is shown in Figure-1 below.

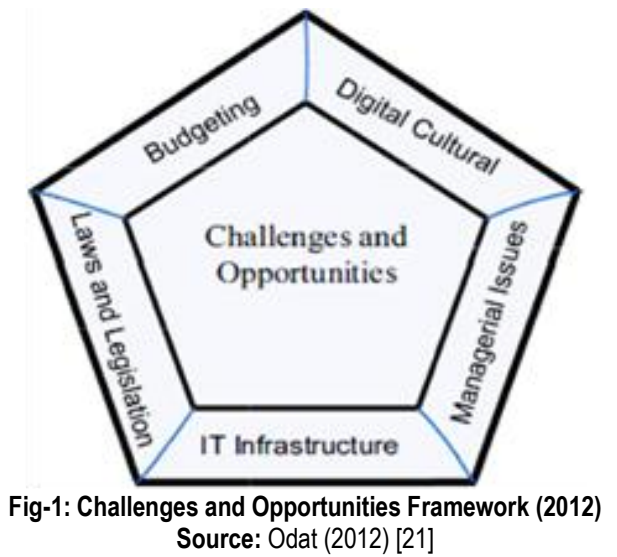

According to Odat [21], IT Infrastructure concerns a lack of technological skills among leaders, employees and citizens, as well as a paucity of hardware and software and knowledge as to their update or maintenance. In addition, there is a lack of communication systems, as well as a lack of digital information. This includes a scarcity of databases with different formats and capacity to archive various document types. In Managerial Issues, Top management and administration should be in support of egovernment programs. They also should have the competency to handle issues such as: workforce turnover and resistance to change; increased transparency in addition to collaboration and coordination among the e-government parties. Meanwhile, Digital Issues include such as digital divide; e-literacy; lack of awareness; trust; security and privacy. Odat [21] also states that concerning Laws and Legislation, the Legislative Assemblies must be able to guarantee that laws are upgraded to perceive e-documents and transactions. Although there has been a rapid advance in the development of systems and applications, there is at the same time an absence of legislations and laws that back the electronic systems and any e-government project is a mega project that needs 
budgeting at all stages. However, developing countries are faced with problems such as: absence of funds; lack of availability of resources management; as well as widespread corruption and misuse of public money.

Advantages of E-government as stated by Zaki [26] are as follows: (a) Transparency: where it provides information on all governmental activities and posts laws and regulations on internet, makes information on procurement available on internet with the aim of equality among all suppliers. (b) Expenses reduction: to minimize number of employees who work on keeping, copying, transferring and distributing paperwork which saves efforts and minimizes cost of a lot of traditional transactions. (c) Increasing quality of e-services through providing services via internet, which allows citizens to access to services at any time and from anywhere, to perform transactions quickly, and to eliminate individual differences in staff performance to prevent negative services. (d) Citizens are able to recover information quickly which enhances relationship with citizens. (d) Integrating with governmental organizations via rapid communications that connect these organizations with each other which saves time and effort of citizens. (e) Reducing the phenomenon of administrative corruption by making data and information available on internet and giving citizens the right to accountability as for the decisions made by managers, which supports the popular control pertaining to public opinion as can be seen in Figure 2 below.

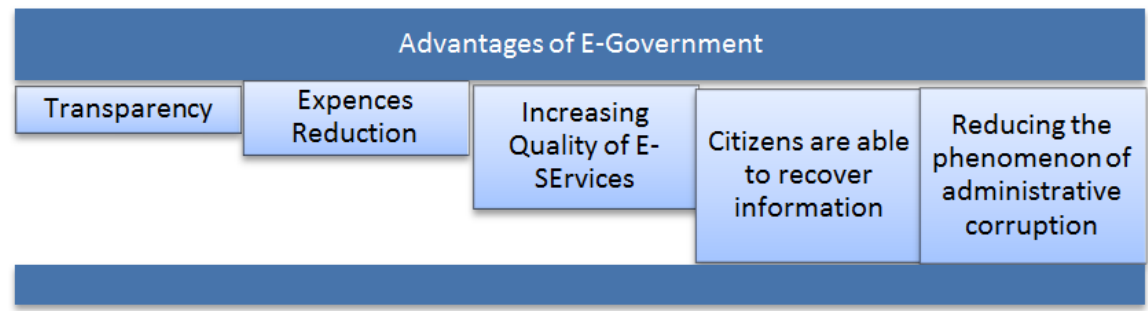

Fig-2: Advantages of E-Government

Source: Zaki (2009, pp: 24-25) [26]

Meanwhile Khamayseh [27] states that E-Government advantages is to obtain required information quickly and accurately and in a legal and systematic manner (not for smart people only); to deliver services to citizens where they are despite the geographical distance, which helps; to provide a non-centralized services; citizens can complete their transactions via internet using the smart cards which contribute to saving time that is wasted in filling required forms; to reduce number of visits to the governmental departments to give citizens opportunities to promote productivity at personal and national levels.

The barriers and challenges to E-Government in developing countries are numerous and difficult and they relate to all organizational, technological, economic, social and legal aspects. It is not easy to overcome the effect of all these obstacles since great efforts are needed from both governments and citizens.

\section{Barriers faced by Indonesian Government in implementing the E- Service Delivery}

Coleman [28] claims that the Fourth Industrial Revolution has a serious impact on society and business due to the digital transformation in the manufacturing sector. Schwab [29] identifies four weaknesses associated with the Fourth Industrial Revolution which include inter-arlia: (a) customer expectations; (b) product enhancement; (c) collaborative innovation; and (d) on organizational reforms [29].

The imminent Fourth Industrial Revolution which seeks to revolutionize the physical, digital and biological worlds came at a time when citizens are demanding service delivery from governments. Therefore the advent of new technologies enables citizens to express their opinions through social networks (facebook, whatsapp, twitter) and other online platforms which is fundamental in facilitating e-participation, thereby, enhancing the social accountability of governments [30].

E-Government adoption requires a high level of satisfaction from both citizens and businesses. A high satisfaction level will succeed in increasing the E-Government adoption rate. It will also ensure transparency in government operations and restore trust in governments [30]. E-Government services have become a significant and active means for interaction among government, citizens and businesses. However, there is as yet no commonly accepted definition [31], despite many definitions existing in literature. Some of them focus only on using ICT (especially the Internet) to deliver high quality government services. Other definitions view EGovernment as a wide and all-encompassing effort for transforming government and governance [32].

The competence of civil servants in the country still needs to be improved. The results of the assessment and competency (talent pool) of the National Personnel Agency (BKN) to thousands of civil servants showed less encouraging results. The results of the talent pool in general show that civil servants are not able to work in teams, lacking innovation, to lack motivation. This talent pool was conducted randomly by BKN to 696 high-ranking officials and 2,670 administrators. The talent pool results are not much different from one region compared to other regions. Results from year to year still show the same pattern. If we look at Indonesian civil servants from their competency side and their potential is still not very high, "Even many of the civil servants do not dare to innovate. In addition, the talent pool shows that civil servants are reluctant to work in teams. There is a tendency to choose to work individually. 
The team building capability is absent. The talent pool results show that the academic title held by a civil servant does not guarantee its competence. For this reason, an evaluation is needed to determine the competencies of civil servants. This certainly has an impact on performance that is not optimal.

In addition to various unfavorable conditions as described above, the development of E-Gov in Indonesia is proof that the understanding of the potential of telematics, especially E-Gov, is still low. This alarming condition occurs at all levels and types of businesses, both in the bureaucracy and in the private sector. The use of E-Gov to reduce the occurrence of various incidents of fraud, crime, to terror that began with the falsification of identity such as ID cards and passports has not shown signs of improvement. This is also the case with various cases of smuggling and misuse of customs documents which are even more widespread and increasingly sophisticated in the mode of operation [33].

Even at the appointment of the last civil servant, almost $58 \%$ came from honorary staff. The lack of expertise owned by civil servants has an impact on the management of resources that are not maximized. In Kalimantan, civil servants who understand mining is only $0.03 \%$, while Kalimantan is a mining area. We can imagine how civil servant can regulate the mining and entrepreneurs, if they do not understand it. Up to the present time, there are not many of them who possess Master's and Doctoral degrees. In addition, the mentality of the civil servants must also be addressed. At present, there are many civil servants think that they are the authorities. In fact, they are public servants. They must have a hospitality spirit, not a ruling soul.

With the current condition of the civil servants, it is not surprising if there are many complaints related to their services. According to Peeler [34] the important factor to pursue business successfully is the quality perceived by the customers at the time of availing services. Customer satisfaction is the key element for creating future purchase demand of the particular product or service. Customers have created the challenging environment for the organizations. The services are intangible so these are being judged through the quality attached [34].

Regarding the demands of Industrial Revolution 4.0, where all the civil servants are required to have the skills to operate computers and communicate digitally, this is another obstacle experienced by the Indonesian government. Until now, there are still many civil servants who are not accustomed to communicating with e-mails and still taking notes using paper and pen when writing the meeting minutes, as well as recording incoming and outgoing letters manually.

\section{RESEARCH METHOdS}

This chapter illustrates the procedures used for this research, in regard of the research method and data collections. Ghauri et al., [35] mentioned that research methodology can be expressed as a system of roles and procedures. Saunders et al., [36] stated that research methodology is a theory of how research should be undertaken, including the theoretical and philosophical assumptions upon which the research is based and implications of these for the methods or methods adopted.

Case study is a research methodology that focuses on understanding the dynamics present in a management situation [37]. The case study approach is particularly useful to employ when there is a need to obtain an in-depth appreciation of an issue, event or phenomenon of interest, in its natural real-life context. As defined by Robson [38], "Case study is a strategy for doing research which involves an empirical investigation of a particular contemporary phenomenon within its real life context using multiple sources of evidence. According to Creswell, case studies are a strategy of inquiry in which the researcher explores in depth a program, event, activity, process, or one or more individuals. They are bound by time and activity, and researchers collect detailed information using a variety of data collection procedures over a sustained period of time. Case study research is most often described as qualitative inquiry [39-42]. Qualitative paradigms are broad and can encompass exploratory, explanatory, interpretive, or descriptive aims.

According to Yin, case studies can be used to explain, describe or explore events or phenomena in the everyday contexts in which they occur (Yin). These can, for example, help to understand and explain causal links and pathways resulting from a new policy initiative or service development. According to Blaikie [43], primary data is new data generated from the primary resources through questionnaire, interviews or observations to find answers related to specific research project. Robson [38] said that a case study is a strategy for doing research which involves an empirical investigation of a particular contemporary phenomenon within its real life context using multiple sources of evidence. Bryman and Bell [44] said that case study design often favor qualitative methods, such as 38 participant observation and unstructured interviewing because these methods are important in the generation of an intensive, detailed examination of a case approach.

Data analysis technique used in this research is qualitative analysis technique. The process of data analysis begins by reviewing all data that has been obtained from various sources. Then data reduction was done by making the abstraction. The next step is to organize the data in units. The units were then categorized in the next step. Categorization was done while making coding. The last stage was to check the validity of the data. After this stage was completed, then interpretation of data was done, so that the stages in qualitative data analysis include: data unit processing, data reduction, categorization of data including checking the validity of data, and interpretation of data [45]. 
The participants for in depth interview consists of 15 people namely 9 civil servants from 3 government institutions in Jakarta to gain information about the implementation of E- Service delivery and the barriers that they faced, 3 Human Resources Managers to dig deeper their perspectives on the readiness of the institutions and civil servants to face the IR 4.0. Finally, the interviews were also conducted to IT specialists of 3 institutions to gain information on their perspectives towards the digital competencies of the civil servants.

\section{RESEARCH Findings AND Discussion}

Regarding the problems faced by civil servants at this time, of the 9 civil servants interviewed, all said that until now, not all mechanisms or working procedures in government offices use digital devices. The simplest example is in the secretarial field. Incoming mail and outgoing mail are still recorded manually using books and stationery, whereas in the current digital era, all correspondence should be recorded digitally. In addition, in carrying out communication between divisions or departments, in general government offices still use letters with hard copy and then archived them manually, not in digitalized systems.

In terms of data storage, at the current government office, staff desks still have a large pile of papers which are important documents. Whereas in the current digital era, we have to store data in a computerized way which is more secure. It also makes it easier to search while reducing the use of paper. The paper piles on the tables still dominate the work space in the current government offices, even though we have started to face the Industrial Revolution 4.0 era.

When asked if this was due to the lack of the civil servants skills in technology, 6 of the 9 staff interviewed said that the skills of the staff were indeed lacking and tended to be below standard, but all this could actually be improved by the adoption of firmer rules or policies with the construction of a standard system for example a computer-based secretarial system. The document storage system and others must be digitalized [21]. Thus the assigned Human Resources Team is people who have skills in the related field. If it is deemed lacking in human resources who master the field, then the institution should organize a training or workshop to improve the staff competencies.

In general, training organized by government agencies is less effective. This is because of the cost saving, the institution is not cooperating with professional training institutions and the trainers are taken only from the internal staff.

"So, we can imagine that they do not have any teaching experience. In addition, the evaluation of training results was never done so that the leaders themselves did not know exactly which staff has shown high potential. In addition to the staff, the top management must also have the competence in the field of technology in order to be able to conduct better supervision, be able to increase transparency and coordination among the government agencies" [24].

Interviews conducted with $3 \mathrm{HRD}$ managers showed that to date the biggest complaint from the public is related to services. Services provided by government agencies are considered far below private companies. In terms of the speed of service, the accuracy of the information provided, to the friendliness of the officers is still below the expected standards whereas service is the most important factors in all types of businesses in the service sector [34].

Related to the readiness of civil servants in dealing with IR 4.0, the $3 \mathrm{HRD}$ leaders said that with the strategic policy of civil servants, HR development now relies on staff management reforms in Law Number 5/2014 on Civil Servants, PP Number 11/2017 pertaining to Civil Servant Management, and PP Number 49/2018 concerning Management of contract base staff. Civil servants' planning is in the direction of national development and regional potential, then computer based and online recruitment and selection. Smart civil servant will also become digital talent in all front liners of government services. In addition, institutional talent management from all agencies is integrated to form a national talent pool, then harmonized with corporate talent management, so as to enable the mobilization of talent across sectors, both public and private, which are the focus and priority of national and regional development.

Meanwhile, interviews with 3 IT specialists showed that in fact Indonesia has got a policy related to the E-Government digitalization system, namely the issuance of Presidential Instruction No.3 of 2003 on National Policies and Strategies for EGovernment Development which has 2 main objectives, namely: (1) processing data, information management, management systems and work processes electronically; (2) utilizing information technology advances so that public services can be accessed easily and cheaply by the public in all regions of the country. However, there are still many obstacles. The services provided through the government website have not been supported yet by the effective management and work process systems because the readiness of regulations, procedures and limited human resources greatly limits computerized penetration into management systems and work processes; not yet established a strategy and insufficient budget allocated for E-Government development in each agency; These initiatives are the efforts of the agency individually; thus a number of factors such as standardization, information security, authentication, and a variety of basic applications that enable interoperability between sites reliably, safely, and reliably to integrate management systems and work processes on government agencies into integrated public services, receive less attention; The approach taken alone is not strong enough to overcome the gaps in the ability of the community to access the internet, so that the range of public services that are developed is also limited. 


\section{CONCLUSION}

From the analysis above, it can be concluded that the government institutions in Jakarta still found barriers in implementing the E- Service delivery, even though Indonesia has established a regulation since 2003. The obstacles were caused by the limited knowledge and skills on technology of the staff which was not followed by the effective training management and supervision. Services provided by government agencies are still considered far below private companies. It can be seen from the speed of service and the accuracy of the information provided. In addition, the friendliness of the officers is still below the expected standard. So, the government should immediately improve the quality of the civil servants in order to create excellent E-service delivery. For further study, the researcher recommends to conduct E- Service delivery policy research which is analyzed from different approach.

\section{ACKNOWLEDGEMENT}

The researcher would like to thank STIAMI Institute of Social Sciences which has granted the research including the publication.

\section{REFERENCES}

1. https://www.liputan6.com/bisnis/read/3653839/kepala-bappenas-ungkap-kondisi-dan-kualitas-pns-saat-ini

2. Badan Kepegawaian Negara (BKN). (2019). Data pegawai negeri sipil. http://www.bkn.go.id/statistik-pns

3. Schultz, T. W. (1993). The Economic importance of human capital in modernization. Education Economics, 1(1), 13-19

4. Marimuthu, M., Arokiasamy, L., \& Ismail, M. (2009). Human capital development and its impact on firm performance: Evidence from developmental economics. Journal of international social research, 2(8).

5. Rastogi, P. N. (2002). Sustaining enterprise competitiveness -is human capital the answer. Human System Management, 19(3), 193-203.

6. OECD. (1998). Human Capital Investment: An International Comparison, OECD, Paris.

7. Becker, G. S. (1993). Human Capital: A Theoretical and Empirical Analysis with Special Reference to Education (3rd ed.).Chicago: University of Chicago Press.

8. Wright, P. M., Gardner, L. M., Moynihan, L. M., \& Allen, M. R. (2005). The relationship between human resource practices and firm performance: Examining causal order. Personnel Psychology, 58, 409-446.

9. Garavan, T. N., Morley, M., Gunnigle, P., \& Collins, E. (2001). Human Capital accumulation: The role of human resource development. Journal of European Industrial Training, 25(2/3/4), 48-68.

10. Dess, G. G., \& Picken, J. C. (1999). Creating competitive (dis) advantage: Learning from Food Lion's freefall. Academy of Management Perspectives, 13(3), 97-111.

11. Nonaka, I. (1994). A Dynamic Theory of Organizational Knowledge Creation. Organization Science, 5(1), 14-37.

12. Sveiby, K. E. (1997). The Intangible Assets Monitor. Journal of Human Resource Costing \& Accounting, 2(1), 73-97.

13. Szulanski, G. (1996). Exploring internal stickiness: impediments to the transfer of best practice within the firm. Strategic Management Journal, 17 (Winter Special Issue), 27- 43.

14. Alnachef, T. H., \& Alhajjar, A. (2015). Effect of Human Capital on Organizational Performance: A Literature Review. International Journal of Science and Research, 1154-1158.

15. Nahapiet, J., \& Ghoshal, S. (1998). Social capital, intellectual capital, and the organizational advantage. The Academy of Management Review, 23(2), 242-266. Retrieved from http://www.jstor.org/stable/259373

16. Gratton, L., \& Ghoshal. (2003). Strategic Human Resource Management: Corporate Rhetoric and Human Reality. Oxford: Oxford University Press.

17. Gartner. (2015). Hype Cycle for Human Capital Management Software, 2015. Gartner Research. Published: 04 August 2015. ID: G00278163.

18. Osborne, D., \& Gaebler. (1992). Reinventing Government. Reading, MA, Addison. Wesley.

19. The World Bank Annual Report. (2012). World Bank. (2012). E- Governments. Retrieved From; http://web.worldbank.org/

20. Karokola, G., Kowalski, S., \& Yngstrom, L. (2013). Evaluating a Framework for Securing E-Government Services-A Case of Tanzania. Paper presented at the 46th Hawaii International Conference on System Sciences (HICSS), 1792-1801. IEEE.

21. Odat, A. M. (2012). E-Government in developing countries: Framework of challenges and opportunities. Paper presented at International Conference for the Internet Technology and Secured Transactions, 578-582.

22. Zhang, N., \& Hou, X. (2011). Government Process Management under electronic government and its application. Paper presented at International Conference on E-Business and E-Government (ICEE), 1-4. IEEE.

23. Fang, Z. Y. (2002). E-Government in Digital Era: Concept, Practice and Development. International Journal of the Computer, the Internet and Management, 10, 1-22.

24. Ronaghan, S. A. (2002). Benchmarking e-government: a global perspective. Assessing the progress of the UN member states. United Nations Division for Public Economics and Public Administration \& American Society for Public Administration.

25. Warkentin, M., Gefen, D., Pavlou, P. A., \& Rose, G. M. (2002). Encouraging citizen adoption of E-government by building trust. Electronic Markets, 12(3), 157-162.

26. Zaki, J., Weber, J., Bolger, N., \& Ochsner, K. (2009). The neural bases of empathic accuracy. Proceedings of the National Academy of Sciences, 106(27), 11382-11387. 
27. Khamseh, F. (2003). Evaluation of Ppsycho-Social Factors Affecting In Post-Partum Depression.

28. Coleman, G. (2016). The next industry revolution will not be televised. World Economic Forum. Davos, January 23.

29. Schwab, K. (2016). The Fourth Industrial Revolution, The World Economic Forum. Available at: http://www.weforum.org/pages/the-fourth-industrial-revolution-by-klaus-schwab. Accessed 07 July 2019.

30. Othman, M., \& Razali, R. (2013). Key contributing factors towards successful Electronic Government systems interoperability. Paper presented at International Conference on Research and Innovation in Information Systems (ICRIIS), 302-307. IEEE.

31. Solli, S. H. (2010). Analytical framework for e-government interoperability. Paper presented at the Challenges e-2010 Conference, 1-9. IEEE.

32. Grant, G., \& Chau, D. (2006). Developing A generic Framework for E-government. Advanced Topics in Global Information Management. 5, 72-101.

33. Satrya, E. (2006). Pentingnya Revitalisasi E-Government Di Indonesia. Prosiding Konferensi Nasional Teknologi Informasi \& Komunikasi untuk Indonesia 3-4 Mei 2006, Aula Barat \& Timur Institut Teknologi Bandung

34. Peeler, G. H. (1996). Selling in the quality era. Blackwell Business, USA.

35. Ghauri, P., \& Gronhaug, K. (2005). Research methods in business studies - A practical guide. 3rd edition. Prentice Hall.

36. Saunders, M., Lewis, P., \& Thornhill, A. (2007) Research Methods for Business Students. 4th Edition, Financial Times Prentice Hall, Edinburgh Gate, Harlow.

37. Eisenhardt, K. M. (1989). Agency theory: An assessment and review. The Academy of Management Review, 14(1), 57-74.

38. Robson, C. (2002). Real World Research. A Resource for Social Scientists and Practitioner-Researchers (Second Edition). Malden, Mass.: Blackwell, 624.

39. Creswell, J. W. (2014). Research Design: Qualitative, Quantitative and Mixed Methods Approaches (4th ed.). Thousand Oaks, CA: Sage.

40. Denzin, N. K., \& Lincoln, Y. S. (2011). The SAGE Handbook of Qualitative Research. Thousand Oaks, CA Sage.

41. Merriam, S. B. (2009). Qualitative research A guide to design and implementation. San Francisco, CA Jossey-Bass.

42. Stake, R. E. (2006) Multiple case study analysis. The Guilford Press, New York.

43. Blaikie, N. (2003). Analyzing Quantitative Data. From Description to Explanation. Sage Publication. Thousand Oaks, 353. https://doi.org/10.4135/9781849208604

44. Bryman, A., \& Bell, E. (2003). Business Research Methods. Oxford University Press, Oxford.

45. Moleong, J. L. (2008). Metodologi Penelitian Kualitatif, Bandung: PT Remaja Rosdakarya. 